\title{
Chemical Properties of Tiger nut-Soy Milk Extract
}

\author{
${ }^{1}$ Awonorin, S.O and ${ }^{2}$ Udeozor, L.O \\ ${ }^{I}$ Department of Food Science and Technology, University of Agriculture Abeokute, P.M.B 2240, Abeokute, \\ Ogun State, Nigeria; \\ ${ }^{2}$ Department of Food Science and Technology, Federal University of Technology, Owerri P.M.B 1526, Owerri, \\ Imo State, Nigeria
}

\begin{abstract}
Fresh tigernut and soybean seeds were processed and blended at different proportions to formulate six new products of natural Tigernut-Soy Milk Extract (TSME) samples: (TME: SME)- 100:0=A, 90:10=B, $80: 20=C, 70: 30=D, 60: 40=E$ and 50:50 $=F$ without addition of spices and chemical preservatives. The samples were evaluated for their chemical composition and sensory qualities. Fat and moisture were the major components of the milk sample. Varying proportions significantly $(p<0.05)$ affected the chemical composition of the samples. All the samples had very high moisture content (81.708 to $86.45 \%)$ and fat content ranging from 8.421 to $10.51 \%$. Protein varied from 2.458 to $3.648 \%$. The samples had a fair amount of minerals and vitamins. The $\mathrm{pH}$ of the samples ranged from 4.56 in $\mathrm{F}$ to 4.95 in A. Total calorific value increased as the carbohydrate, protein and fat contents of the milk samples also increased. Total solids increased with a decrease in moisture content. All the samples were highly acceptable ( $p>0.05)$ but sample $E$ (60:40) received the highest (7.4) overall acceptability score. An observable trend was that protein, carbohydrate and fat contents increased with an increase in tigernut milk extract substitution, thus, the provision of an enhanced total energy drink. This is of high nutritional and economic potential.
\end{abstract}

Key words: soy milk extract, tigernut milk extract, varying proportion, chemical properties, quality

\section{Introduction}

Milk is one of the main products in most pastoral system in Africa, yet the contribution of dairying to pastoral economics is often overlooked (Kerven, 1986). In Africa, milk will not only meet $30 \%$ of the pastoral family caloric requirements but, also has a vital exchange value.

It is noteworthy, that the dairy sub sector in Africa is thus relegated to the category of subsistence system of production due to minor and peripheral status accorded the sector by various government policies. Allied with the above, are poor nutrition and genetic constitution of the Africa breeds of ruminants. The above problems lead to insufficient milk available to the people. This dramatic decrease in the consumption of milk and milk products stimulated in part the processing of milk from different seeds and nuts (Belewu and Belewu, 2007).Though undervalued in the past, milk from plant sources are key ingredient in the diet of African countries.

Recently, researchers have shown strong interest in these milk sources due to their high nutritional values and economic potentials. It is worth repeating that milk sources from plants are seen as a radiating hope as well as an ally in the fight against hidden hunger (Belewu and Belewu, 2007).

In view of the scarce milk supply in various countries and the ever increasing gap between the requirement and population, efforts have been made over the years to develop alternative milk-like products from vegetable sources (Singh and Bains, 1988). Soybeans, peanuts and cowpea have been accorded high attention in the investigations on milk substitutes.

However, hardly any attention has been given to the use of locally available tiger-nut as such or in combination with milk to produce a palatable ready-to-serve bottled beverage, like 'Horchata de chufas' as done in South Europe especially in Spain (Mordi et al., 2010).

Tiger-nut (Cyperus esculentus L.) belongs to the Division-Magnoliophyta, Class-Liliopsida, Ordercyperales and Family-Cyperaceae and was found to be a cosmopolitan, perennial crop of the same genus as the papyrus plant. The tubers are about the size of peanuts and are abundantly produced in Nigeria. It has many other names like Zulu nut, yellow nutgrass, ground almond, chufa, edible rush and rush nut. In Nigeria, the Hausas call it "Aya", Yorubas "imumu", the Igbos "aki Hausa", "ofio" in southern Nigeria (Osagie and Eka, 1998). Tiger-nut has been cultivated since early times (chiefly in south Europe and West Africa) for its small tuberous rhizomes which are eaten raw or roasted, used as hog feed or pressed for its juice to make a beverage. Non-drying oil (usually called chufa) is equally obtained from the rhizome.

The nut which is cultivated throughout the world are also found in the Northern part of Nigeria and other West Africa Countries like Guinea, Cote d'ivore, Cameroon, Senegal, America and other parts of the World (Irvine, 1969). 
The nut was found to be rich in myristic acid, oleic acid, linoleic acid (Eteshola \& Oraedu, 1996), with oleic acid being the most abundant (Muhammad et al., 2011). Tiger-nut was reported as very healthy as it helps in preventing heart attacks, thrombosis and activates blood circulation. It is believed that they help to prevent cancer especially of the colon due to high content of soluble glucose. Tiger-nut was equally reported to have positive effect on cholesterol level due to high content of vitamin E. They are thought to be beneficial to diabetics and those seeking to reduce cholesterol or loose weight. The very high fibre content combined with a delicious taste; make them ideal for healthy eating (Osagie and Eka, 1998). The nut is rich in energy content (starch, fat, sugars \& protein), mineral (phosphorus, potassium) and vitamins E and C (Anonymous, 2005). The nut was found to be ideal for children, older persons and sportsmen (Martinez, 2003).

Since the tubers contain $36 \%$ oil, C. esculentus has been suggested as potential oil crop for the production of biodiesel (Muhammad et al., 2011). The oil remained uniformly liquid at refrigeration temperature; this makes the oil suitable for salad making (Umerie and Enebeli, 1997).

Tiger nut was found to be a good substitute for some other (plant) milk sources. The nuts are valued for their highly nutritious starch content, dietary fibre, carbohydrate (mono, di and polysaccharides) (Umerie and Enebeli, 1997). The nut was reported to be rich in sucrose (17.4 to $20.0 \%)$, fat $(25.50 \%)$, and protein (8\%) (Kordylas, 1990). The nut is also very rich in mineral content (Sodium, Calcium, Potassium, Magnesium, Zinc and traces of Copper (Omode et al., 1995). Research studies have shown that 100g Tiger-nuts contain $386 \mathrm{kcal}$ $(1635 \mathrm{~kJ}), 7 \%$ proteins, $36 \%$ fats (oils), $31 \%$ starch, $21 \%$ glucose, and $26 \%$ fibre of which $14 \%$ is non-soluble and $12 \%$ soluble (Muhammad et al., 2011).

Tiger-nuts are regarded as a digestive tonic having a heating and drying effect in digestive system and alleviating flatulence. They also promote urine production. The nuts are said to be stimulant and tonic and also used in the treatment of indigestion, colic diarrhoea, dysentery and excessive thirst (David, 1986).

Tiger-nut milk (having Spanish name "Horchata") is a refreshing purely natural vegetable drink and/ or desert, which is prepared with water, sugar and tiger-nuts. It is a very nutritive, energy drink both for young and old. "Being highly nutritious would make it an ideal drink during the holy month of fasting, De Ramadan" (Tiger nut Traders, 2009). It is high in starch, natural fat, glucose and protein. Also rich in minerals like, potassium, phosphorus and vitamins $\mathrm{C}$ and $\mathrm{E}$. In the face of soy milk and other soy products, tiger nut milk has never been found to produce any allergy. It contains no sodium, which makes it perfect for people with high tension (Tiger nut Traders, 2009).

The qualities of Tiger-nut (Cyperus esculentus) in this context stimulate its inclusion in the preparation of beverage so as to provide protein-energy-rich drink at affordable price in place of animal protein/fat which is scarce and expensive.

Soybean (Glycine max M) with $40 \%$ protein and $20 \%$ fat assumes the most predominant position in solving the nutritional imbalances prevailing. It not only provides quality macronutrients but also various other micronutrients, which are otherwise required to fight against malnutrition.

Soybean is rich in protein content and can furnish protein supply to bridge up the protein deficiency gap at low-cost than any other crop (Rehman et al., 2007). Among the numerous soy food items, soymilk (extract of soybean) had been the first product ever prepared and consumed by human since long ago. Soymilk not only provides protein but also is a source of carbohydrate, lipid, vitamins and minerals (Chien and Snyder, 1983).

Soymilk is an alternate of dairy animal milk due to its cheaper high-quality protein.

Soymilk is a healthy drink and is important for people who are allergic to cow milk protein and lactose. In spite of its nutritional merits, it has not gained much popularity mainly due to its beany flavour and astringency (Cheman et al., 1989).

The implication of using the two different milk sources in the diet is the high contents of protein and fat. The total energy value of the milk is from the fat content hence, higher fat content is an indication of more total energies available (Belewu and Belewu, 2007).

The objectives of this work therefore were to produce a protein-energy-rich milk drink from tiger-nut and soy bean, and to determine the quality attributes of tiger nut-soy milk drink and consumer acceptability of tiger-nut beverage.

\section{Materials and methods}

Fresh Tiger nuts and soybean seeds were purchased from the local traders in Eke-onunwa market in Owerri, Imo State, Nigeria. The equipment and chemicals used were obtained from Nigerian Institute of Science Laboratory Technology (NISLT), Samonda, Ibadan, Oyo State and Anthony Van-Leeuwenhoek Research Centre, Nekede, Owerri, Imo State.

Sample preparation: Fresh tubers of tigernuts and soybean seeds were sorted; foreign materials, bad/cracked nuts and seeds which may affect the taste and keeping quality of the drink were removed, washed and rinsed with portable water and used to produce milk. 
Tigernut milk extract: $1 \mathrm{~kg}$ of the fresh tigernuts was blended several times into slurry with water $(6 \mathrm{~L})$ in a Qlink auto-clean blender. The slurry was pressed using muslin cloth to extract the milk. The extract was pasteurized at $72^{\circ} \mathrm{C}$ for $15 \mathrm{~s}$. It was homogenized, bottled when hot and rapidly cooled. The flow chart for tigernut milk extract (TME) production is shown in Fig.1.

Soybean milk extract: $1 \mathrm{~kg}$ of soybeans was soaked overnight for $18 \mathrm{~h}$ in a $3 \mathrm{~L}$ of warm portable water to give a bean: water ratio of 1:3. The beans were then drained, rinsed with treated water and blanched for $5 \mathrm{~min}$ in boiling water. The blanched beans were drained, dehulled and ground with $750 \mathrm{ml}$ of treated water in a Q-link autoclean blender. The resulting slurry was filtered through a muslin cloth and the extract (milk) obtained was boiled for $15 \mathrm{~min}$. The flow chart for soymilk extract (SME) production is shown in Fig.2.

Tigernut-Soy milk extract (TSME) preparation: Tigernut milk extract (TME) and soymilk extract (SME) were mixed at varying proportions (TM:SM); 100:0, 90:10, 80:20, 70:30, 60:40 and 50:50 to obtain the final product (TSME). This was done using a food blender operated at full speed for $10 \mathrm{~min}$. The resulting blends were homogenized and pasteurized at $72^{\circ} \mathrm{C}$ for $15 \mathrm{~s}$ in a water bath, hot-filled into sterile bottles (leaving $1 \mathrm{~cm}$ head space), cooled to room temperature $\left(28 \pm 2^{\circ} \mathrm{C}\right)$ and then stored in a refrigerator at $4{ }^{\circ} \mathrm{C}$ until analysed. All analyses were carried out in duplicate for each sample; results obtained were computed into means and subjected to analysis of variance (ANOVA). The flow chart for tigernut-soymilk extract production is shown in Fig.3.

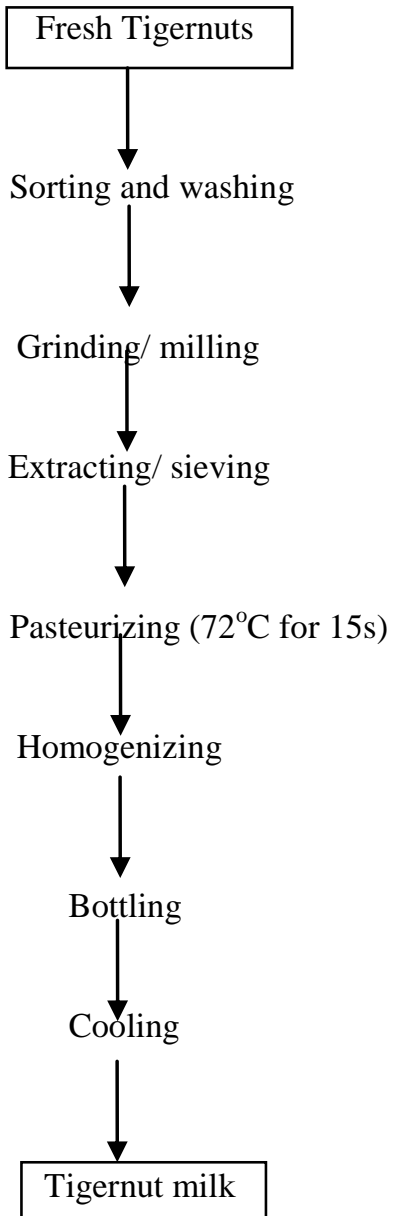

Fig.1: Flow chart for Tigernut milk extract (TME) production. 


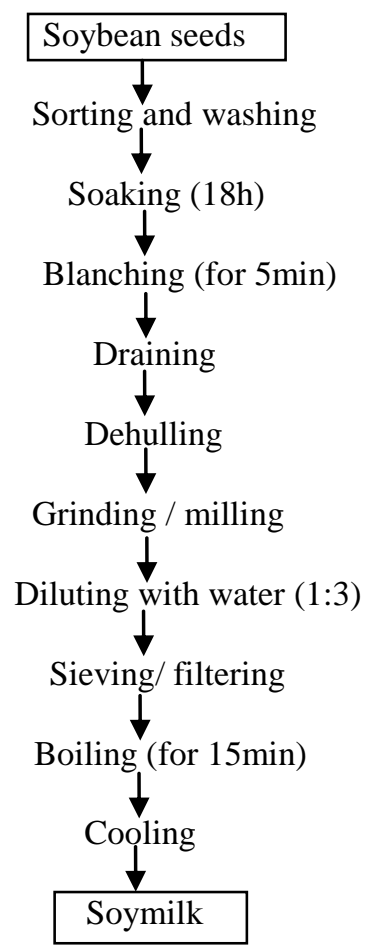

Fig.2: Flow chart for soy milk extract (SME) production.

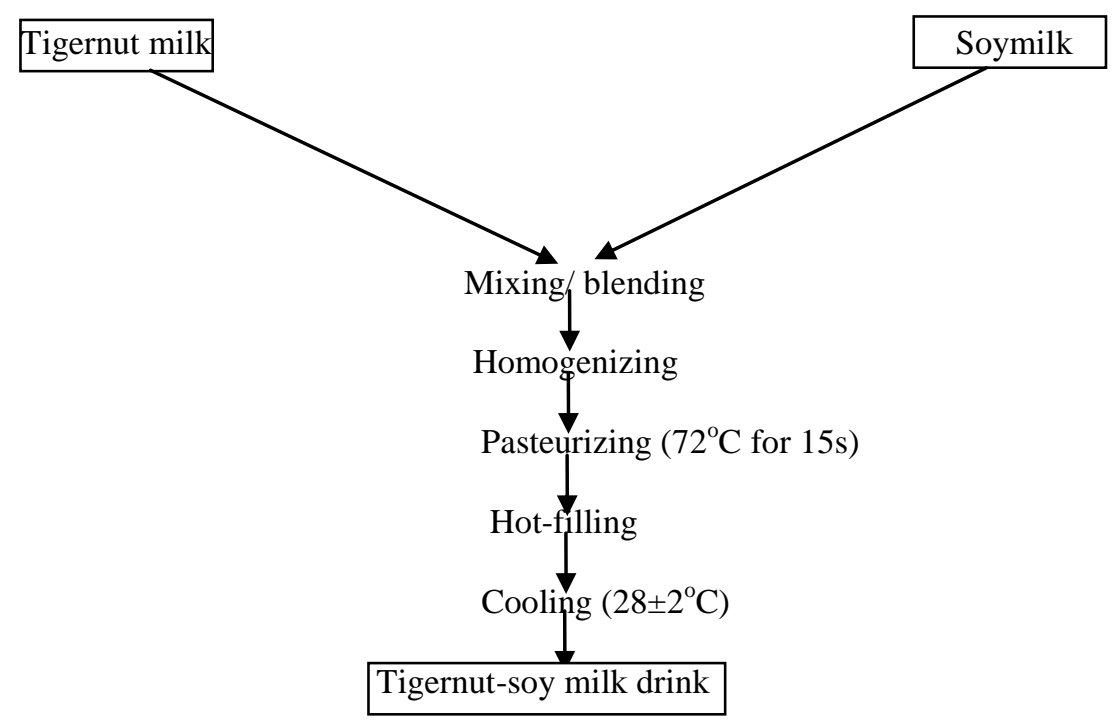

Fig. 3: Flow chart for the production of Tigernut-Soy Milk Extract.

Chemical Analysis:

\section{Analyses}

Titratable Acidity Determination: This was determined according to AOAC (1990) method. Twenty (20) ml of the beverage sample was measured into a conical flask and 2 drops of $1 \%$ phenolphthalein indicator was added to the mixture and titrated with $\mathrm{O} .1 \mathrm{~N} \mathrm{NaOH}$ against a white background. The result was recorded as soon as the first appearance of a pink colour was observed. Titration continued until the colour persisted. The results obtained were calculated as follows:

T.T.A $=\quad$ Number of $\mathrm{ml}$ of $\mathrm{NaOH}$ used Sample taken 
Moisture Content Determination: This was done by the gravimetric method according to AOAC (1990). Ten (10) $\mathrm{ml}$ of the beverage sample was measured into a can that has been earlier washed, dried in an oven and weighed. The sample in the can was dried in the oven at a temperature of $105^{\circ} \mathrm{C}$ for $3 \mathrm{~h}$. After $3 \mathrm{~h}$, it was cooled in a desiccator and weighed. It was then returned to the oven for further drying. Drying, cooling and weighing were done repeatedly at 30min interval until a constant weight was obtained. The weight of the moisture lost was calculated and expressed as a percentage of weight of samples analyzed. This was given by the expression below:

$$
\begin{aligned}
& \text { \% moisture: } \quad \frac{\mathrm{W}_{2}-\mathrm{W}_{3}}{\mathrm{~W}_{1}} \quad \mathrm{x} \frac{100}{1} \\
& \text { where, } \mathrm{W}_{2}=\quad \text { Weight of can }+ \text { sample before drying } \\
& \mathrm{W}_{3}=\quad \text { Weight of can }+ \text { sample after drying } \\
& \mathrm{W}_{1}=\quad \text { Weight of sample used. }
\end{aligned}
$$

Total Solids Determination: This was determined according to AOAC (1990) method. Ten (10) ml of the beverage sample was filtered through a pre-weighed Whattman glass fibre filter paper inserted in a funnel fitted in a $500 \mathrm{ml}$ capacity Buchner flask. After the filtration, the glass fibre was carefully removed and placed on a cleaned Petri-dish using a pair of thong and oven dried at $105^{\circ} \mathrm{C}$ for $1 \mathrm{~h}$. After the stipulated time, it was removed and cooled in a desiccator for 30min and then reweighed. The drying, cooling and weighing was repeated until a constant weight was obtained. The total suspended solid was then calculated as:

mg suspended solids $/ \mathrm{L}=$

where:
A-B $\times 1000$

Volume of sample used (ml)

$\mathrm{A}=$ total weight of glass fibre filter + residue $(\mathrm{mg})$

$\mathrm{B}=$ weight of glass fibre filter (mg)

Ash Content Determination: The method described by James (1995) was used. Ten (10) ml of the beverage samples was measured into a previously weighed porcelain crucible. This was transferred into a muffle furnace and heated at $550^{\circ} \mathrm{C}$ for $2 \mathrm{~h}$. The ashing continued until all the samples became completely ash. The crucible and its content were cooled in a dessicator and re-weighed. The percentage ash was calculated.

$\%$ Ash:<smiles>[Mg][W]#[W]</smiles>

$\mathrm{x}$ 100

where, $\mathrm{W}_{2}=$

$$
\begin{aligned}
& \mathrm{W}_{3}= \\
& \mathrm{W}_{1}=
\end{aligned}
$$

Weight of sample + crucible

Weight of empty crucible

Weight of sample used.

Fat Content Determination: The fat content was determined using the method as described by James (1995). Twenty (20) $\mathrm{ml}$ of the beverage samples was measured, evaporated to dryness on a water bath and transferred to an oven. Ten (10) grams of the dried sample was weighed and put in a soxhlet reflex flask containing $200 \mathrm{ml}$ petroleum ether. The upper end of the reflux flask was connected to a condenser by heating the solvent in the flask through electron thermal heater; it vaporizes and condenses into the reflux flask. Soon the sample was immersed in the solvent and remained in contact with it until the flask filled up and siphoned over, thus carrying oil extract from the sample down to the boiling flask. This process lasted for $4 \mathrm{~h}$ before the defatted sample was removed. The solvent was recovered and the extracting flask with its oil content was dried in the oven at $60^{\circ} \mathrm{C}$ for $3 \mathrm{~min}$ (i.e. to remove residual solvent). After cooling in a dessicator, the flask was re-weighed. Its fat content was calculated as:

$$
\% \text { fat }=\frac{\mathrm{W}_{2}-\mathrm{W}_{3}}{\mathrm{Wt} \text { of sample }} \times \frac{100}{1}
$$

where:

$\mathrm{W}_{3} \quad=\quad$ Weight of empty extraction flask

$\mathrm{W}_{2} \quad=\quad$ Weight of flask and oil extract

Crude Fibre Determination: This analysis was done using the AOAC (1990) method. Twenty (20) ml of the beverage sample was measured and poured into hot $200 \mathrm{ml} 1.25 \% \mathrm{H}_{2} \mathrm{SO}_{4}$ and boiled for $30 \mathrm{~min}$ in a beaker. The hot acid sample solution was filtered; the residue was poured into $200 \mathrm{ml}$ boiling $1.25 \% \mathrm{NaOH}$ and boiled for $30 \mathrm{~min}$. It was filtered and progressively washed with boiling water, alcohol and petroleum either. The residue was drained out and it was transferred completely to a porcelain crucible and dried in an oven at $150^{\circ} \mathrm{C}$ to a constant mass. It was cooled and weighted and incinerated at $600^{\circ} \mathrm{C}$ for $2 \mathrm{~h}$ in muffle furnace. The crucible and the content were weighted after cooling in a dessicator. The loss of incineration is the mass of crude fibre.

$$
\% \text { Crude Fibre }=\frac{\mathrm{M}_{2}-\mathrm{M}_{4}}{\mathrm{M}_{2}-\mathrm{M}_{1}} \times \frac{100}{1}
$$




where, $\begin{array}{lll}\mathrm{M}_{1} & = & \text { Mass of crucible } \\ \mathrm{M}_{2} & = & \text { Mass of sample }+ \text { crucible } \\ \mathrm{M}_{3} & = & \text { Mass of crucible + residue } \\ \mathrm{M}_{4} & = & \text { Mass of crucible }+ \text { ash after incineration }\end{array}$

Crude Protein Determination: The protein content of the beverage was determined by the micro-kjedahl method as reported by James (1995). Ten (10) $\mathrm{ml}$ of the beverage sample was weighed into a micro Kjedahl flask. A tablet of selenium catalyst and $5 \mathrm{ml}$ of concentrated tetraoxosulphate (VI) acid $\left(\mathrm{Conc} . \mathrm{H}_{2} \mathrm{SO}_{4}\right)$ were added. Another $5 \mathrm{ml}$ samples was measured and the same treatment stated above was given to it. The sample in the flask was digested at red hot temperature in a fume cupboard for $2 \mathrm{~h}$. The digests were transferred into a volumetric flask each. Meanwhile, the digestion was evidenced by a clear solution obtained after the $2 \mathrm{~h}$. Each of the transferred digests was diluted to $50 \mathrm{ml}$ with distilled water. Ten (10) $\mathrm{ml}$ of each dilution was pipette into 'Markham' apparatus with gradual introduction of $10 \mathrm{ml}$ of $40 \% \mathrm{NaOH}$. Each mixture was distilled by steampowered heat and distillate collected into $10 \mathrm{ml}$ of $4 \%$ Boric acid solution containing 3 drops of mixed indicator, $50 \mathrm{ml}$ of distillate from each duplicate was titrated with $0.02 \mathrm{NH}_{2} \mathrm{SO}_{4}$ to a pink colour. The percentage Nitrogen calculation in each was multiplied with a factor 6.25 to get percentage protein.

Calculation:

The total Nitrogen content was calculated using the relationship that $1 \mathrm{ml}$ of $\mathrm{H}_{2} \mathrm{SO}_{4}=14 \mathrm{mg}$ of $\mathrm{H}_{2} \mathrm{SO}_{4}$ thus,

\begin{tabular}{|c|c|c|c|}
\hline $\mathrm{W}$ & \multicolumn{3}{|c|}{$100 \times \mathrm{N} \times 14 \times \underline{\mathrm{Vt}} \times \mathrm{T}-\mathrm{B}$} \\
\hline where; & $\mathrm{T}$ & $=$ & Titre value of the sample \\
\hline & B & $=$ & Blank titre value \\
\hline & $\mathrm{Ca}$ & $=$ & Volume of digest distilled \\
\hline & $\mathrm{Vt}$ & $=$ & Total volume of digest \\
\hline & $\mathrm{N}$ & $=$ & Normality of acid used \\
\hline & $\mathrm{W}$ & $=$ & Weight of sample used. \\
\hline & $\mathrm{Cr}$ & & $P)=\% \mathrm{~N}_{2} \times 6.25$ \\
\hline
\end{tabular}

Carbohydrate Determination: Carbohydrate was calculated by difference method according to AOAC (1990). $\%$ carbohydrate $=100-(\%$ moisture $+\%$ ash $+\%$ crude protein $+\%$ crude fibre $+\%$ fat $)$.

Ascorbic Acid Determination: The vitamin C content of the beverage sample was determined by the barakal isometric method as described by Pearson (1976). Twenty (20) $\mathrm{ml}$ of sample was mixed with 0.02NEDTA by blending for $5 \mathrm{~min}$ in a blender. The homogenate was filtered and the filtrate used for the analysis. Each test sample was passed through a packed cotton wool containing activated charcoal to remove colour. The volume of the filtrate was adjusted to $100 \mathrm{ml}$ and $20 \mathrm{ml}$ of the filtrate was measured into a conical flask. Ten (10) $\mathrm{ml}$ of $20 \%$ potassium solution was added to each of the flasks followed by $5 \mathrm{ml}$ of starch solution (indicator). The mixture was done to an end point marked by black specks of the brink of the mixture. The vitamin $\mathrm{C}$ content was given by the relationship that $1 \mathrm{ml}$ of $0.01 \mathrm{ml} \mathrm{CuSO}_{4}$ solution $=0.88 \mathrm{mg}$ Vitamin $\mathrm{C}$. Therefore, Vitamin $\mathrm{C}$ is calculated by:

$\begin{array}{llllll}\text { Vit. } \mathrm{C}=\frac{100}{\mathrm{~W}} & \mathrm{x} & 0.88 & \mathrm{x} & \frac{\mathrm{Vt}}{\mathrm{Va}} & \mathrm{x}\end{array}$ Titre

where,

$$
\begin{array}{lll}
\mathrm{W} & = & \text { Weight of sample used } \\
\mathrm{Vt} & = & \text { Total extract volume used } \\
\mathrm{Va} & = & \text { Volume of extract titrated }
\end{array}
$$

Vitamin A (Retinol) Determination: Vitamin A was determined as described by James (1995). A measured $20 \mathrm{ml}$ of the beverage sample was dispersed in $30 \mathrm{ml}$ absolute alcohol and $3 \mathrm{ml}$ of $50 \%$ potassium hydroxide solutions was added to it and under reflex for 30min. After cooling rapidly under running water, 30ml of distilled water were added and the mixture transferred to a separating funnel. After separation the lower aqueous layer was discarded while the upper lay was washed with distilled water and in each case, the wash out water was discarded. The extract was evaporated almost to dryness and dissolved in $10 \mathrm{ml}$ of isopropyl alcohol. Meanwhile a standard solution was prepared and diluted to a desired concentration in 10ml isopropyl alcohol. The absorbance of the standard vitamin A solution and that of the test sample extract solution was separately measured at $325 \mathrm{~nm}$ with a spectrophotometer. The vitamin A content was calculated thus:

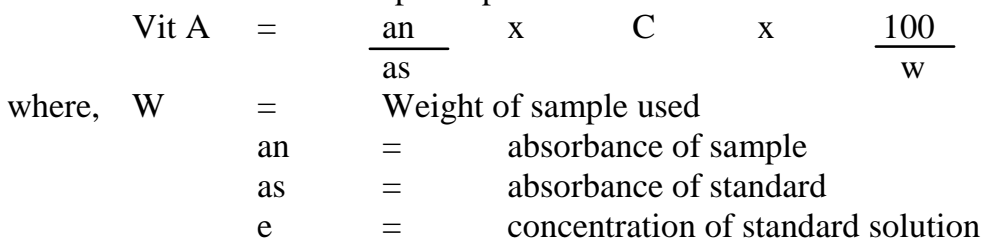


Calorie Determination: Food total energy was estimated using the modified Atwater factor ( $4 \mathrm{x}$ protein $+4 \mathrm{x}$ carbohydrate $+9 \mathrm{x}$ fat) (Hunt et al., 1987).

Determination of Minerals: The mineral contents of the test samples were determined by the dry ash extraction method following each specific mineral element as described by James (1995). Twenty (20) ml of the samples was burnt to ash on a muffle (as in ash determination and the resulting ash was dissolved in $100 \mathrm{ml}$ of dilute hydrochloric acid (1MHCL) and then diluted to $100 \mathrm{ml}$ volumetric flask using distilled water. The solution was used for the various analysis of mineral.

Calcium and Magnesium Determination: Calcium and magnesium contents of the test sample were determined by the EDTA complex isometric titration. Twenty (20) $\mathrm{ml}$ of each extract was dispersed into a conical flask and panels of the masking agents, hydroxytannin, hydrochlorate, and potassium cyanide were added followed by $20 \mathrm{ml}$ of ammonia buffer ( $\mathrm{pH} \mathrm{10.0).} \mathrm{A} \mathrm{pinch} \mathrm{of} \mathrm{the} \mathrm{indicator-Ferrochrome} \mathrm{black} \mathrm{was} \mathrm{added}$ and the mixture was shaken very well. It was titrated against $0.02 \mathrm{~N}$ EDTA solution. A permanent blue colour was observed and the reading taken. Blank titration consisting of $20 \mathrm{ml}$ distilled water was also treated as described above.

Titration for calcium alone was a repeat of the previous one with slight change, $10 \% \mathrm{NaOH}$ solution at $\mathrm{pH} 12.0$ was used in place of ammonia buffer while solechrome dark blue was used as an indicator in place of Ferrochrome black. The calcium and magnesium contents were calculated using the formulae below.

Cal or $\mathrm{Mg}(\mathrm{mg} / 100 \mathrm{~g})=\frac{100}{\mathrm{~W}} \mathrm{x} \quad \mathrm{Ew} \times \frac{\mathrm{N}}{100} \times \frac{\mathrm{Vt}}{\mathrm{Va}} \mathrm{T}$

where, $\begin{array}{lll}\mathrm{W} & = & \text { Weight of sample used } \\ \mathrm{Ew} & = & \text { Equivalent weight of the sample } \\ \mathrm{Vt} & = & \text { Total volume of extract } \\ \mathrm{Va} & = & \text { Volume of extract titrated } \\ \mathrm{N} & = & \text { Normality of EDTA } \\ \mathrm{T} & = & \text { Titre value of blank solution }\end{array}$

Potassium and Sodium Determination: The potassium and sodium of the beverage sample was determined by photometric method. The instrument was set up according to the manufacture's instruction. The equipment was switched on and allowed to stay for about $10 \mathrm{~min}$. The gas and air inlets were opened as the start knob was turned on. The equipment being self-igniting, the flame was adjusted to a non-luminous level until a blue colour was obtained. Meanwhile standard $\mathrm{K}$ and $\mathrm{Na}$ solutions were prepared separately and each was diluted to concentrations of 2, 4, 6, 8, $10 \mathrm{ppm}$. Starting with the least concentration of 2ppm, all the standard solution were sucked into the instrument and caused to spray over the non-luminous flame. The reading were recorded and later plotted into a standard curve and used to extrapolate to $\mathrm{K}$ level in the sample. After the standard, the beverage solutions were siphoned in turns into the instrument with their reading recorded.

The samples were repeated with sodium standard. The concentration of the test mineral in the sample was calculated with reference to the curve and obtained as follows:

$\begin{array}{llll}\mathrm{K} \text { or } \mathrm{Na}(\mathrm{mg} / 100 \mathrm{~g}) & & =100 \mathrm{x} \frac{\mathrm{Vt}}{\mathrm{W}} \frac{\mathrm{X}}{10^{3}} \\ \text { Where, } & \mathrm{W} & = & \text { Weight of sample used } \\ \mathrm{Vt} & = & \text { Total extract volume } \\ \mathrm{X} & = & \text { Concentration K/Na from the graph } \\ \mathrm{D} & = & \text { Dilution factor }\end{array}$

Iron Determination: AOAC (1990) method was used to determine the iron content. Two (2) $\mathrm{ml}$ of the test sample was weighed and first digested with $20 \mathrm{ml}$ of acid mixture $\left(650 \mathrm{ml}\right.$ Conc. $\mathrm{HNO}_{2}, 80 \mathrm{ml}$ Perchloric acid (PCA) and $20 \mathrm{ml}$ Conc. $\mathrm{H}_{2} \mathrm{SO}_{4}$ ) and aliquot of diluted clear digest was used for atomic absorption spectrophotometer. The solution was heated until a clear digest was obtained. The digest was diluted with distilled water to the $100 \mathrm{ml}$ mark, which now served as sample solution for atomic absorption spectrophotometer reading. A standard solution of iron was prepared and was used to plot the calibration curve. The concentration of iron was calculated by extrapolation using the standard curve.

$\begin{array}{rlll}\text { Fe mg/100g } & = & & \mathrm{Vt} \\ \text { Where, } \quad & & & \text { Ta } \\ \mathrm{Vt} & = & & \text { Total volume of extract/digest } \\ \mathrm{Va} & = & & \text { Volume of digest used } \\ \mathrm{X} & = & & \text { Concentration of iron } \\ \mathrm{W} & = & \text { Weight of sample } \\ \mathrm{D} & = & & \text { Dilution factor }\end{array}$

pH Determination: The method of A.O.A.C (1990) was used. The $\mathrm{pH}$ meter was first standardized with a buffer solution of $\mathrm{pH} \mathrm{7,} \mathrm{so} \mathrm{as} \mathrm{to} \mathrm{calibrate} \mathrm{the} \mathrm{pH}$ meter. The samples were measured out, in a beaker and the 
electrode was rinsed with distilled water before dipping it into the milk samples and the result obtained were recorded. The readings obtained were multiplied by the factor.

Sensory Evaluation: Samples were subjected to sensory evaluation using twenty panelists randomly selected from the university community. The samples were coded and presented to the panelists using white glass cups. Water was provided for mouth wash in between evaluations. Panelists rated the products for overall acceptability and sensory attributes of colour, aroma, taste and mouthfeel. A 9-point hedonic scale (Ihekoronye and Ngoddy, 1985) was used for rating.

Statistical Analysis: Data obtained were subjected to Analysis of Variance (ANOVA) and Turkey's test was used for comparison of means. Statistical significance was accepted at $5 \%$ probability level $(\mathrm{p}<0.05)$ as described by Ihekoronye and Ngoddy (1985).

Results obtained from chemical analysis were also computed into means and the analysis of variance (ANOVA) was carried out.

\section{Results and Discussion}

\section{Proximate composition of Tigernut-Soy milk products:}

The proximate composition of tigernut-soy milk extract (TSME) is shown in Table 1. Fat, in addition to moisture, was quantitatively a major component of the beverage. The beverage samples were fairly rich in protein and carbohydrate. In fact, tigernut drink contains more carbohydrates than the cow's milk (Chevallier, 1996). Ash and Crude fibre were found to be sparsely present. An observable trend was that protein, carbohydrate and fat contents increased with increase in tigernut milk substitution.

Carbohydrate content: The milk samples had carbohydrate contents between 1.31 to $2.483 \%$. Sample F (50:50) had the highest value $(2.483 \%)$ which was significantly different $(\mathrm{p}<0.05)$ from other samples. There was no significant difference ( $>$ > 0.05) between samples B, C, D, and E. Sample A (100:0) had the least value $(1.31 \%)$ but did not differ significantly ( $p>0.05$ ) from Samples B, C, and D. Blending (combination of two milk sources), however, increased the carbohydrate content of the milk samples. Several workers have confirmed the presence of high carbohydrate content in tigernut (Ade-Omowaye et al., 2008).

Protein content: From Table 1, protein contents of the milk samples ranged between 2.458 to $3.648 \%$ with sample F (50:50) having the highest value. A similar work done by Ukwuru et al. (2011) showed that protein increased with increase in tigernut substitution. The results agreed with the report of Belewu et al. (2005); Belewu et al. (2010). Protein content was higher for Tigernut-Soy Milk Drink than for Tigernut Milk Drink and Soy Milk Drink (Udeozor, 2012). High crude protein of TSMD could probably be due to high crude protein of Tigernut. Eka and Ohaba (1977) also found similar protein increase in tigernut. No signicant difference ( $p$ > 0.05 ) existed among all the samples.

Fat content: Fat in the samples was said to be the major component aside moisture contents. From Table 1, fat contents ranged between 8.421 to $10.51 \%$ with sample $F(50: 50)$ as the highest; differing $(p<0.05)$ significantly from other samples and sample A (100:0) as the least. No significant difference ( $p>0.05)$ existed between samples A and B; samples B, C and D; and samples C, D and E. The higher value of sample F (50:50) compared to sample A (100:0) may be attributed to higher content of fat in the tigernut and soybean. Tigernut, itself was reported to be rich in fat (25.50\%) according to Belewu and Abodunrin (2006). The level in the milk samples was higher than the minimum (3\%) recommended level by the Codex Alimentarius Standard (Passmore and Eastwood, 1986).

Crude fibre content: Processing, however, affected the crude fibre content of the samples as they were very low compared to the high crude fibre content of the tigernuts. In Table 1, Sample F (50:50) had the highest fibre content (0.533), while sample A had the least (0.391). No significant difference ( $p>0.05)$ existed among samples.

Moisture content: In Table 1, moisture contents varied from 81.708 to $86.450 \%$. This variability may be due to the composition of the samples. Sample A had the highest value (86.450\%) and does not differ significantly (p> 0.05 ) from samples B, C and D. No significant difference ( $>>0.05$ ) existed among samples $C, D$ and $E$. All samples differed significantly $(\mathrm{p}<0.05)$ from sample $\mathrm{F}$ which had the least value $(81.708 \%)$. This implies that sample A with the highest moisture is more susceptible to spoilage than the other samples by microbial invasion especially fungi and mould (Ihekoronye and Ngoddy, 1985). Although all the samples had high moisture contents that could affect the stability and safety of the products with respect to microbial growth and proliferation, hence, the products require cold storage for shelf-life extension.

Ash content: The values ranged from 0.288 to $0.495 \%$, sample $\mathrm{F}$ had the highest value of $0.635 \%$ while sample $\mathrm{D}$ recorded the least value of $0.288 \%$ as shown in Table 1 . No significant $(\mathrm{p}>0.05)$ difference in ash content existed among all the samples. Total ash in the samples was lower than ash content of $1.5 \%$ as reported by Ukwuru et al. (2008). Ash indicates the measure of minerals in a food commodity. The variation in ash content may be due to variation in inorganic compounds especially calcium ion present in milk extracted from tigernut and soybean. 
Table 1: Mean values for proximate composition of tigernut-soy milk extract (TSME) obtained from varying

\begin{tabular}{l|l|l|l|c|c|c}
\multicolumn{7}{c}{ proportions } \\
\hline Sample & $\begin{array}{l}\text { CARBOHY } \\
\text {-DRATE (\%) }\end{array}$ & PROTEIN (\%) & FAT (\%) & FIBRE (\%) & MOISTURE (\%) & ASH (\%) \\
\hline A & $1.310^{\mathrm{c}}$ & $3.365^{\mathrm{a}}$ & $8.421^{\mathrm{d}}$ & $0.391^{\mathrm{a}}$ & $86.450^{\mathrm{a}}$ & $0.478^{\mathrm{a}}$ \\
B & $1.468^{\mathrm{bc}}$ & $2.458^{\mathrm{a}}$ & $8.820^{\mathrm{cd}}$ & $0.437^{\mathrm{a}}$ & $86.405^{\mathrm{a}}$ & $0.343^{\mathrm{a}}$ \\
C & $1.500^{\mathrm{bc}}$ & $2.873^{\mathrm{a}}$ & $9.188^{\mathrm{bc}}$ & $0.255^{\mathrm{a}}$ & $85.743^{\mathrm{ab}}$ & $0.308^{\mathrm{a}}$ \\
D & $1.583^{\mathrm{bc}}$ & $2.613^{\mathrm{a}}$ & $9.157^{\mathrm{bc}}$ & $0.428^{\mathrm{a}}$ & $85.958^{\mathrm{ab}}$ & $0.288^{\mathrm{a}}$ \\
E & $1.780^{\mathrm{b}}$ & $2.837^{\mathrm{a}}$ & $9.683^{\mathrm{b}}$ & $0.350^{\mathrm{a}}$ & $84.827^{\mathrm{b}}$ & $0.358^{\mathrm{a}}$ \\
F & $2.483^{\mathrm{a}}$ & $3.648^{\mathrm{a}}$ & $10.510^{\mathrm{a}}$ & $0.533^{\mathrm{a}}$ & $81.708^{\mathrm{c}}$ & $0.495^{\mathrm{a}}$ \\
\hline LSD & 0.449 & $\mathrm{~ns}$ & 0.671 & $\mathrm{~ns}$ & 1.214 & $\mathrm{~ns}^{2}$
\end{tabular}

Means with different superscript in each column are significantly different $(\mathrm{p}<0.05)$. LSD $=$ Least Significant Difference; ns= Not Significant; $A=100 \%$ tigernut milk+0\% soymilk; B $=90 \%$ tigernut milk $+10 \%$ soymilk; $C=$ $80 \%$ tigernut milk+20\% soymilk; $\mathrm{D}=70 \%$ tigernut milk $+30 \%$ soymilk; $\mathrm{E}=60 \%$ tigernut milk $+40 \%$ soymilk; $\mathrm{F}=$ $50 \%$ tigernut milk+50\% soymilk.

\section{Mineral and Vitamin contents of Tigernut-Soy milk products:}

Mineral content: The results of the mineral contents in Table 2 showed that the samples were rich in minerals. This concurs with the reports of Omode et al. (1995) who found that the nut is very rich in mineral content. Magnesium and Iron had the higher contents as against calcium and sodium which had the least. Significant difference $(p<0.05)$ existed among the samples for magnesium, iron and calcium while in samples for potassium and sodium; no difference existed ( $\mathrm{p}>0.05$ ). The values ranged from 2.062 to $3.250 \%, 1.2$ to $1.92 \%$, 0.543 to $0.69 \%, 0.094$ to $0.291 \%$ and 0.182 to $0.286 \%$ for magnesium, iron, potassium, calcium and sodium, respectively. The calcium contents of these samples fell within the range reported by Belewu and Belewu (2007). For magnesium, sample F had the highest value $(3.250 \%)$, while sample A $(2.062 \%)$ had the least; for iron, sample F had the highest value (1.92\%) while sample A (1.2\%) had the least; for potassium, sample F had the highest value $(0.69 \%)$ while sample D $(0.543 \%)$ had the least; for calcium, sample $\mathrm{F}$ had the highest value $(0.291 \%)$ while sample B $(0.094 \%)$ had the least; for sodium, sample F had the highest value $(0.286 \%)$ while sample A $(0.182 \%)$ and $\mathrm{D}(0.182 \%)$ had the least values. The higher values for sample $\mathrm{F}$ in all the proportions were expected due to equal combination (50:50) of the two milk sources. Tigernut drink contains more iron and magnesium than the cow's milk (Chevallier, 1996).

Vitamin content: According to the results in Table 2, appreciable amount of vitamins (A and C) were found in the samples. For vitamin A, the values varied and ranged from 0.773 to $1.258 \mu \mathrm{g} / 100 \mathrm{~g}$. Sample A (100\% tigernut milk) had the highest vitamin A content and D had the least vitamin A content. It could be observed that with increased substitution of tigernut milk, the vitamin A content decreased. This may be attributed to higher content of vitamin A (and or yeasts, a precursor of vitamin A) in tigernut than in soymilk. For vitamin $\mathrm{C}$, the values ranged from 0.75 to $1.28 \%$. Sample $\mathrm{F}$ had the highest vitamin $\mathrm{C}$ content while sample B had the least vitamin $\mathrm{C}$ content. Vitamin $\mathrm{C}$ is very unstable since it oxidizes easily, thus, it is used as an index of quality (Onyeka, 2008). Pasteurization of the milk samples was done at lesser temperature thereby preventing heat liable nutrients from being lost. This explains why vitamin $\mathrm{C}$ was present though in small amount. Significant difference existed $(\mathrm{p}<0.05)$ among all samples in the vitamins $(A$ and $C)$. Soymilk not only provides protein but also is a source of carbohydrate, lipid, vitamins and minerals (Chien and Snyder, 1983). Tigernut is a rich source of nutrients such as vitamins $\mathrm{C}$ and $\mathrm{E}$, and minerals such as phosphorus, magnesium, potassium, calcium, iron, and also carbohydrates, unsaturated fats, proteins and some enzymes which can help in the digestive system (Tiger nut Traders, 2009).

Table 2: Mean values for mineral and vitamin contents of tigernut-soy milk extract (TSME) obtained from varying proportions

\begin{tabular}{l|l|l|l|l|l|c|c}
\hline SAMPLE & $\begin{array}{l}\text { POTASSIUM } \\
(\%)\end{array}$ & $\begin{array}{l}\text { CALCIUM } \\
(\%)\end{array}$ & $\begin{array}{l}\text { SODIUM } \\
(\%)\end{array}$ & $\begin{array}{l}\text { MAGNESIUM } \\
\mathrm{mg} / \mathrm{l}\end{array}$ & $\begin{array}{l}\text { VITAMIN A } \\
\mu \mathrm{g} / \mathrm{l}\end{array}$ & $\begin{array}{l}\text { VITAMIN C } \\
(\%)\end{array}$ & $\begin{array}{l}\text { IRON } \\
\mathrm{mg} / \mathrm{l}\end{array}$ \\
\hline $\mathrm{A}$ & $0.564^{\mathrm{a}}$ & $0.101^{\mathrm{b}}$ & $0.182^{\mathrm{a}}$ & $2.327^{\mathrm{b}}$ & $1.258^{\mathrm{a}}$ & $1.017^{\mathrm{bc}}$ \\
$\mathrm{B}$ & $0.663^{\mathrm{a}}$ & $0.094^{\mathrm{b}}$ & $0.187^{\mathrm{a}}$ & $2.062^{\mathrm{b}}$ & $1.072^{\mathrm{ab}}$ & $0.800^{\mathrm{cd}}$ \\
$\mathrm{C}$ & $0.608^{\mathrm{a}}$ & $0.082^{\mathrm{b}}$ & $0.186^{\mathrm{a}}$ & $2.165^{\mathrm{b}}$ & $1.128^{\mathrm{a}}$ & $00.750^{\mathrm{c}}$ \\
$\mathrm{D}$ & $0.543^{\mathrm{a}}$ & $0.110^{\mathrm{b}}$ & $0.215^{\mathrm{a}}$ & $2.562^{\mathrm{ab}}$ & $0.773^{\mathrm{c}}$ & $1.600^{\mathrm{ab}}$ \\
$\mathrm{E}$ & $0.621^{\mathrm{a}}$ & $0.122^{\mathrm{b}}$ & $0.182^{\mathrm{a}}$ & $2.655^{\mathrm{ab}}$ & $0.807^{\mathrm{c}}$ & $0.876^{\mathrm{bcd}}$ \\
$\mathrm{F}$ & $0.690^{\mathrm{a}}$ & $0.291^{\mathrm{a}}$ & $0.286^{\mathrm{a}}$ & $3.250^{\mathrm{a}}$ & $0.852^{\mathrm{bc}}$ & $1.078^{\mathrm{ab}}$ \\
\hline LSD & $\mathrm{ns}$ & 0.123 & $\mathrm{~ns}$ & 0.725 & 0.241 & $1.288^{\mathrm{bc}}$ \\
\hline
\end{tabular}

Means with different superscript in each column are significantly different $(\mathrm{p}<0.05)$. LSD = Least Significant Difference; ns= Not Significant; $A=100 \%$ tigernut milk+0\% soymilk; $B=90 \%$ tigernut milk $+10 \%$ soymilk; $C=$ 
$80 \%$ tigernut milk+20\% soymilk; $\mathrm{D}=70 \%$ tigernut milk $+30 \%$ soymilk; $\mathrm{E}=60 \%$ tigernut milk $+40 \%$ soymilk; $\mathrm{F}=$ $50 \%$ tigernut milk+50\% soymilk.

Physico-chemical properties of Tigernut-Soy milk products:

Table 3: Mean values for physico-chemical propertties of tigernut-soy milk extract (TSME) obtained from

\begin{tabular}{l|l|l|l|l}
\multicolumn{5}{c}{ varying proportions } \\
\hline SAMPLE & $\begin{array}{l}\text { TOTAL SOLID } \\
(\mathrm{mg} / \mathrm{l})\end{array}$ & $\begin{array}{l}\text { TOTAL ACIDITY } \\
(\%)\end{array}$ & $\mathrm{pH}$ & $\begin{array}{l}\text { TOTAL ENERGY } \\
(\mathrm{cal})\end{array}$ \\
\hline $\mathrm{A}$ & $6.988^{\mathrm{a}}$ & $26.585^{\mathrm{a}}$ & $4.953^{\mathrm{a}}$ & $94.488^{\mathrm{c}}$ \\
$\mathrm{B}$ & $6.372^{\mathrm{a}}$ & $26.547^{\mathrm{a}}$ & $4.728^{\mathrm{a}}$ & $95.088^{\mathrm{c}}$ \\
$\mathrm{C}$ & $6.498^{\mathrm{a}}$ & $24.777^{\mathrm{a}}$ & $4.800^{\mathrm{a}}$ & $100.188^{\mathrm{bc}}$ \\
$\mathrm{D}$ & $6.598^{\mathrm{a}}$ & $25.558^{\mathrm{a}}$ & $4.753^{\mathrm{a}}$ & $99.197^{\mathrm{bc}}$ \\
$\mathrm{E}$ & $6.855^{\mathrm{a}}$ & $25.167^{\mathrm{a}}$ & $4.840^{\mathrm{a}}$ & $105.617^{\mathrm{b}}$ \\
$\mathrm{F}$ & $7.223^{\mathrm{a}}$ & $26.250^{\mathrm{a}}$ & $4.562^{\mathrm{a}}$ & $119.117^{\mathrm{a}}$ \\
\hline LSD & $\mathrm{ns}$ & $\mathrm{ns}$ & $\mathrm{ns}$ & 6.520
\end{tabular}

Means with different superscript in each column are significantly different $(\mathrm{p}<0.05)$. LSD = Least Significant Difference; ns= Not Significant; $A=100 \%$ tigernut milk $+0 \%$ soymilk; $B=90 \%$ tigernut milk $+10 \%$ soymilk; $\mathrm{C}=80 \%$ tigernut milk $+20 \%$ soymilk; $\mathrm{D}=70 \%$ tigernut milk $+30 \%$ soymilk; $\mathrm{E}=60 \%$ tigernut milk $+40 \%$ soymilk; $\mathrm{F}=50 \%$ tigernut milk $+50 \%$ soymilk.

Total solids (TS): From the Table 3, it could be inferred that total solids of the milk samples increased with decrease in moisture content. Sample F had the highest TS value of $7.223 \mathrm{mg} / 1$ while sample B had the least TS value of $6.372 \mathrm{mg} / \mathrm{l}$. This is in agreement with the report of Ukwuru and Ogbodo (2011) that used different processing treatments for tigernut milk production. No significant difference $(p>0.05)$ existed between samples. With this reduction in moisture content, nutrient composition increased thereby increasing the total solids of the milk samples.

Titrable Acidity (TA): In Table 3, the TA values ranged from 24.777 to $26.585 \%$. Sample A gave the highest value while sample $\mathrm{C}$ gave the least value. No significant difference $(\mathrm{p}>0.05)$ existed between samples. Research has shown that as TSS $\left(\%\right.$ Brix $\left.^{\circ}\right)$ increases, $\mathrm{pH}$ increases and TA drops, also as TSS and pH drop, TA increases.

pH: The pH value for milk samples ranged from 4.562 to 4.953 in Table 3. Sample A had the highest $\mathrm{pH}$ value while sample $\mathrm{F}$ had the least $\mathrm{pH}$ value. No significant difference ( $\mathrm{p}>0.05)$ existed among all the samples. These values were lower than that reported for tigernut milk products by Ukwuru and Ogbodo (2011) except for the UHT Milk (with $\mathrm{pH}$ of 4.4 because of lime addition) and were not comparable to the $\mathrm{pH}$ of melon seed milk (6.25), cowpea milk (6.79) and soymilk (6.6) reported by Akubor (1998); Nnam (2003) and Onweluzo and Owo (2005), respectively. This is advantageous because it will discourage the growth of pathogens that may cause gastrointestinal problems (Ukwuru and Ogbodo, 2011).

Total energy (Cal): Table 3 showed that caloric value was highest for sample F (119.117), closely followed by sample E (105.617) and least for sample A (94.488). Sample F was significantly different $(p<0.05)$ from samples E, D, C which were similar ( $p>0.05$ ) and samples A, B between which no significant difference existed ( $p>0.05)$. It could be inferred that total caloric value increased with increase in the carbohydrate, protein and fat contents of the milk samples. The total energy value of the milk comes mainly from the fat content; hence, higher fat content is an indication of more total energies available (Belewu and Belewu, 2007).

\section{Sensory quality of Tigernut-Soy milk products:}

The sensory scores for tigernut-soy milk extract obtained by varying proportions are presented on Table 4. All samples were rated alike in almost all the sensory attributes evaluated indicating the minimal effect varying proportion had on the organoleptic property of the milk.

Table 4: Mean values for sensory qualities of fresh tigernut-soy milk extract with varying proportions

\begin{tabular}{|c|c|c|c|c|c|}
\hline \multirow[t]{2}{*}{ Sample } & \multicolumn{4}{|c|}{ Sensory qualities } & \multirow[b]{2}{*}{ Overall acceptability } \\
\hline & Colour & Aroma & Taste & Mouthfeel & \\
\hline A & $6.85^{\mathrm{b}}$ & $5.45^{\mathrm{a}}$ & $5.8^{\mathrm{a}}$ & $5.3^{\mathrm{a}}$ & $6.7^{\mathrm{ab}}$ \\
\hline B & $7.4^{\mathrm{ab}}$ & $5.3^{\mathrm{a}}$ & $5.95^{\mathrm{a}}$ & $5.8^{\mathrm{a}}$ & $6.95^{\mathrm{ab}}$ \\
\hline $\mathrm{C}$ & $7.5^{\mathrm{ab}}$ & $5.85^{\mathrm{a}}$ & $6.15^{\mathrm{a}}$ & $5.8^{\mathrm{a}}$ & $7.25^{\mathrm{a}}$ \\
\hline D & $7.3^{\mathrm{ab}}$ & $6.05^{\mathrm{a}}$ & $6.35^{\mathrm{a}}$ & $5.55^{\mathrm{a}}$ & $6.0^{\mathrm{b}}$ \\
\hline E & $7.85^{\mathrm{a}}$ & $6.0^{\mathrm{a}}$ & $5.95^{\mathrm{a}}$ & $6.55^{\mathrm{a}}$ & $7.4^{\mathrm{a}}$ \\
\hline $\mathrm{F}$ & $7.85^{\mathrm{a}}$ & $6.35^{\mathrm{a}}$ & $6.1^{\mathrm{a}}$ & $5.7^{\mathrm{a}}$ & $6.2^{\mathrm{b}}$ \\
\hline LSD & 0.69 & 1.24 & 1.80 & 1.30 & 0.98 \\
\hline
\end{tabular}

Means with different superscript in each column are significantly different $(\mathrm{p}<0.05)$. LSD $=$ Least Significant Difference; A=100\% tigernut milk+0\% soymilk; B= 90\% tigernut milk+10\% soymilk; $\mathrm{C}=80 \%$ 
tigernut milk $+20 \%$ soymilk; $\mathrm{D}=70 \%$ tigernut milk $+30 \%$ soymilk; $\mathrm{E}=60 \%$ tigernut milk $+40 \%$ soymilk; $\mathrm{F}=50 \%$ tigernut milk $+50 \%$ soymilk.

There was no significant difference ( $p>0.05$ ) observed between various samples in terms of aroma, taste and mouthfeel. Sample F had the highest score for aroma (6.35) while sample B had the least score (5.3). Sample D had the highest score for taste (6.35). Sample E and F had the highest score for colour (7.85). The tigernut-soy milk drinks had creamy colour just like conventional milk (dairy milk). The uniformity in colour could be attributed to the same processing treatment. The exception was sample A which had the least mean score for colour (6.85). Also, the taste and mouth feel of sample A were least than those of other samples. Sample E was rated highest in terms of mouth feel and overall acceptability. The high mean score of sample E for mouth feel could be attributed to its high fat content. Fat is known to promote good mouth feel (Onweluzo and Nwakalor, 2009). However, the panelists commented that all the milk drinks were good but sample E was the best. Sample D was least preferred. Unlike other phytomilk, tigernut milk has no beany flavour and throat catching sensations. Significant $(\mathrm{p}<0.05)$ difference was observed only in colour and overall acceptability between the various samples.

Despite the significant differences in sensory quality in some tigernut-soy milk extract as earlier mentioned, all the beverage samples were generally acceptable to the panelists. Similar blend carried out on orange-tigernut beverage (Ukwuru et al., 2011) recorded high acceptability. Such acceptability has led to the commercialization of tigernut milk products in Spain (Tigernut Traders, 2009).

\section{Conclusion}

The combination of tigernut milk extract and soymilk extract resulted in milk (beverage) with improved nutrient composition and organoleptic properties. Thus, tigernut and soybean could be used as a beverage for both the young and old persons due to these nutrient potentials (high protein, fat, total energy contents, etc) and to diversify diets. Based on the sensory evaluation, the tigernut-soy milk extract at 60:40\% (sample E) was most preferred, although all the drink samples recorded high acceptability by the panelists. Also the blend helped to mask the "beany" flavour of the soymilk as commented by the panelists. This indicates that utilization of tigernut will be enhanced when processed into beverage drinks. It is therefore suggested that milk extract from tiger-nut and soybean be encouraged because such beverage will be helpful in reducing nutritional related problems (such as protein-calorie malnutrition) in Africa in particular and the world in general; as these milk extract also possess almost similar properties as that of cow milk.

\section{Recommendation}

It will be necessary, however, to determine the effect of different types of chemical preservatives and their varying quantities on the tigernut-soy milk extract.

\section{Acknowledgement}

Technical assistance of Okwaegbe, Anthony A. is hereby acknowledged.

\section{Reference:}

[1]. A.O.A.C., (1990). Official method of Analysis 15th (ed). Association of official Analytical Chemist, Washington D.C. U.S.A. Pp. $121-142,223-225$

[2]. Ade-Omowaye, B.I.O., B.A. Akinwande, I.F. Bolarinwa and A.O. Adebiyi, (2008). Evaluation of tigernut (Cyprus esculentus) wheat composite flour and bread. African Journal of Food Science, 2: 87-91.

[3]. Akubor, P.I., (1998). Physico-chemical and sensory characteristics of melon seed milk. Journal of Food Science; 35: 93-95.

[4]. Anonymous, (2005). Tigernut and health. http://www.tigernut.com/salud.html

[5]. Belewu , M.A. and K.Y. Belewu, (2007). Comparative Physico- Evaluation of Tiger-nut, Soybean and Coconut Milk Sources. Int. J. Agric. Biol. 9:785-787.

[6]. Belewu MA and OA Abodunrin. (2006). Preparation of Kunnu from unexploited rich food source: Tiger nut (Cyperus esculentus). World Journal of Dairy and Food Sciences; 1: 19-21.

[7]. Belewu MA, Belewu KY, Olatunji SA (2005). Soy-Coconut Yoghurt: Preparation, Compositional and organoleptic Qualities. BioScience Res. Bulletin 21 ( 2 ) : 129-137.

[8]. Belewu, M.A., Belewu, K.Y and Bamidele, R.A. (2010). Cyper-coconut yoghurt: preparation, compositional and organoleptic qualities. Afr. J. Food Sci.Technol. Vol. 1(1) pp. 010-012

[9]. Cheman, Y.B., L.S. Wei and A.I. Nelson, (1989). Acid inactivation of soybean lipoxygenase with retention of protein solubility. J. Food Sci., 54: 963-967.

[10]. Chevalier, A., (1996). The Encyclopedia of medicinal plants. Dorling Kindersley Press, London. ISBN 9: 980/54 303148.

[11]. Chien, J.T. and H.E. Snyder, (1983). Detection and control of soymilk astringency, J. Food Sci., 48: 438-440.

[12]. David, F. (1986). Human nutritional dietary. Food Encyclopedia. Pp. 35-36.

[13]. Eteshola .E, and A.C.I Oraedu, (1996). Fatty acids composition of Tigernut tubers (Cyperus esculentus), Baobab seeds (Adansonia digitata L.) and their mixturesJ. American Oil Chemists Society 73: 255-257

[14]. Hunt, C., P. Burn and Z.C Adamezuk,(1987). Proximate composition and Fat type of three popular take away meal. Int. J. Food Sci.Technol., 22: 669-75

[15]. Ihekoronye, A.I and Ngoddy, P.O. (1985). Integrated Food Science and Technology for the tropics. Macmillian Publishers Ltd. London. Pp.178- 180, 305-306, 372-373. 
[16]. Irvine, F.R., (1969). West African Crops Longman Publishers, pp: 26.

[17]. James, S.C. (1995). Analytical Chemistry of Food. Chapman and Hill Printers. London. Pp. 23.

[18]. Kerven, C., (1986). Some Research and Development implication for pastoral dairy production in Africa. ILCA Bull., 26: 29-35

[19]. Kordylas, J.M., (1990). Processing and Preservation of Tropical and subtropical food. J. Agri.Food Tech., 13: 28-40.

[20]. Martinez, V. (2003). Scientific analysis of effects of tiger nut on heart diseases and related aspects In: Tiger Nut and Health. Pp. 12 .

[21]. Mordi, J. I., A.U. Ozumba, G. N. Elemo and O. Olatunji. (2010). Physicochemical and Sensory Evaluation of Nigerian Tiger-Nut Extract Beverage. Biosci. Res. Commun. Vol. 22, No. 4 pp: 203- 207

[22]. Muhammad, N.O, Bamishaiye, E.I, Bamishaiye, O.M, Usman, L.A, Salawu, M.O, Nafiu, M.O and Oloyede, O.B. (2011). Physicochemical Properties and Fatty Acid Composition of Cyperus esculentus (Tiger Nut) Tuber Oil. Bioresearch Bulletin 5: 5154.

[23]. Nnam, N.M. (2003). Nutrient composition and acceptability of vegetable milk, made from oil seeds. J. Home Econ. Res., 5: 57-61.

[24]. Omode, A., O. Fatoki and K.A. Olaogun, (1995). Physicochemial properties of some under-exploited and non-conventional oil seed. J. Agri. Food Chem., 14: 50-53.

[25]. Onweluzo, J.C. and C. Nwakalor, (2009). Development and evaluation of vegetable milk from Treculia Africana (Decne) seed. Park. J. Nutr., 8: 233-238.

[26]. Onweluzo, J.C. and O.S. Owo, (2005). Stabilization potential of water soluble polysaccharide from two legumes (Deterrummisso carpum and Mukurafla gellipes) in vegetable milk: Effects on selected quality characteristics. J.Home Econ. Res., 6: 39- 44.

[27]. Onyeka, U.E. (2008). Food and Nutrition. 2nd ed. Characteristic Forum Publications. No. 21. Mbaise Road, Owerri, Nigeria, Pp. 157.

[28]. Osagie AU and OU Eka. (1998). Nutritional quality of plant foods. Post- harvest research unit, University of Benin, Nigeria. Pp 246-249.

[29]. Passmore, R. and W.A. Eastwood, (1986). Human Nutrition and Dietetics. 8th Edn., New York, English

[30]. Pearson, D. (1976). The Chemical Analysis of Food. (17 ${ }^{\text {th }}$ edition). Churchill Living Stone Edumburgh. Pp. $94-126$.

[31]. Rehman, S., S. Hussain, H. Nawaz, M.M. Ahmad, N. Huma and W.A. Virk, (2007). Preparation and quality evaluation of lathyrus sativus L-bovine milk blend. Pak. J. Nutr., 6: 134-137.

[32]. Singh, T. and G.S. Bains, (1988). Grain extract-milk beverage, processing and physico-chemical characteristics. J. Food Sci., 53:1387-1390.

[33]. Tigernuts Traders, (2009). Tigernuts/Chufas Tigernuts Traders, S.L. Available online. www.tigernuts.com. Accessed Sept 13, 2009

[34]. Udeozor, L.O. (2012). Tigernut-Soy Milk Drink: Preparation, Proximate Composition and Sensory Qualities. Intr. J. Food and Nutri. Sci.,1 (4): 18-26.

[35]. Ukwuru, M.U., C.L. Ibeneme and G.I. Agbo (2011). New Product Development from Tigernut (Cyperus esculentus) and Their Sensory, Proximate and Microbiological Evaluation. Pak. J. Nutr., 10 (2): 101-105,

[36]. Ukwuru, M.U., L.J. Omachona and N. Onokah, (2008).Production and quality assessment of tigernut (Cyperus esculentus) imitation milk during storage. J. Food Sci. Technol., 45: 180-182.

[37]. Umerie, S.C. and J.N. Enebeli, (1997). Malt caramel from the nuts of Cyperus esculentus. J. Bio. Resource Tech., pp: 215-216. 